\title{
Metal Content and Stable Isotope Determination in Some Commercial Beers from Romanian Markets
}

\author{
Cezara Voica, Dana-Alina Magdas, and Ioana Feher \\ National Institute for R\&D of Isotopic and Molecular Technologies, 67-103 Donat Street, P.O. Box 700, 400293 Cluj-Napoca, Romania
}

Correspondence should be addressed to Dana-Alina Magdas; amagdas@itim-cj.ro

Received 17 March 2015; Revised 8 May 2015; Accepted 12 May 2015

Academic Editor: Jose M. Jurado

Copyright (C) 2015 Cezara Voica et al. This is an open access article distributed under the Creative Commons Attribution License, which permits unrestricted use, distribution, and reproduction in any medium, provided the original work is properly cited.

Characterization of beer samples is of interest because their compositions affect the taste and stability of beer and, also, consumer health. In this work, the characterizations of 20 Romanian beers were performed by mean of Inductively Coupled Plasma Mass Spectrometry (ICP-MS) and Isotope Ratio Mass Spectrometry (IRMS) in order to trace heavy metals and isotopic content of them. Major, minor, and trace metals are important in beer fermentation since they supply the appropriate environment for yeast growth and influence yeast metabolism. Beside this, the presence of the $\mathrm{C}_{4}$ plants in the brewing process was followed. Our study has shown that the analyzed beers indicated the presence of different plant types used in brewing: $C_{3}, C_{3}-C_{4}$ mixtures, and also $C_{4}$, depending on producers. Also the trace metal content of each sample is presented and discussed in this study. A comparison of the beers quality manufactured by the same producer but bottled in different type of packaging like glass, dose, or PET was made; our results show that no compositional differences among the same beer type exist.

\section{Introduction}

Beer is a product of a yeast alcoholic fermentation of extracts of malted cereals, usually barley malts, with or without a starchy material, and to which hops are added. All natural components used for brewing, including water, cereals, barleys, and yeasts, are the main endogenous sources of metals in beer. For that reason, the mineral composition of beer reflects the composition of ingredients used for brewing and refers to processes involved in a beer production. The characterization of beer samples has received a lot of interest because their composition can affect the taste and stability of beer and consumer health [1]. The assessment of the total composition of beer, including the determination of major, minor, and trace metals, is of particular interest and notice to the brewers and the consumers since, independent of the concentration and type, they might be essential or toxic in the human body and they can also have an influence on the brewing process and the quality of beer in view of the flavor stability or the formation of haze [2]. Information on the total metal content of beer is recognized to be valuable for differentiation and classification of beer [3-5]. This is because metals are very good descriptors reflecting the composition of natural raw products (water, cereals, hops, and yeasts) used for brewing and indicating processes involved in beer manufacturing, as well as beer storage and ageing.

There is growing interest in the application of ICP-MS to foods analysis, for the purposes of ensuring food safety and ensuring flavor/quality. Inductively coupled plasma mass spectrometry (ICP-MS) is a multielement technique with a wide range of analytical applications, with high selectivity and sensitivity and low analytical limits, so that it is an excellent tool for detailed characterization of elemental composition of beverages. ICP-MS can also be used for identifying cases of food adulteration and confirming origin by trace element "fingerprinting." Within the last few years, stable isotope analysis has gained increasing importance in authenticity control of food and food ingredients.

The use of stable isotope analysis provides one of the most effective tools to detect food adulteration and is based on measurements of stable isotope contents either on a product or a specific component it the product. In the case of carbon, the carbon isotope ratio in food products is directly related to their botanical origin. Thus, carbon isotope ratios $\left(\delta^{13} \mathrm{C}\right)$ represent a valuable tool to detect the presence of $\mathrm{C}_{4}$ plants (corn, cane sugar, etc.) in the brewing process due to 
the isotopic differences that appear between the two plants categories: $\mathrm{C}_{3}$ (barely, rice, etc.) and $\mathrm{C}_{4}$ plants (corn, cane sugar, etc.).

The application of multivariate statistical techniques such as analysis of variance (ANOVA) and cluster analysis (CA) offers the possibility to understand the large amount of data generated by analytical techniques based on the overall properties of the samples and to perform a classification without the need for additional compositional chemical data [6]. ANOVA analysis (comparison between groups) is a statistical method which is used for revealing the differences between two or more means from distinct groups. Cluster analysis is an unsupervised pattern recognition that is trying to determine relationships between objects (samples) without using any prior information about these relationships [7].

\section{Materials and Methods}

The samples were purchased from local markets and represent the most well-known beer commercialized on Romanian market. Twenty different blonde, dark beer samples bottled in various forms as glass bottles, dose, or PET were used in this study in order to evaluate market available beers quality. All of them contained alcohol between ranges of $4.5-7 \%$ reported to the whole beer volume.

\subsection{Inductively Coupled Plasma Mass Spectrometry (ICP-MS) Analysis}

2.1.1. Apparatus. The analytical measurements were carried out with a PerkinElmer ELAN DRC (e) ICP-MS apparatus, equipped with a Meinhard nebulizer and glass cyclonic spray chamber for pneumatic nebulization.

2.1.2. Materials and Reagents. Ultrapure deionized water $\left(18 \mathrm{M} \Omega \cdot \mathrm{cm}^{-1}\right)$ from a Milli-Q analytical reagent grade water purification system (Millipore) and ultrapure concentrated $\mathrm{HNO}_{3}$ (Merck) were used. A solution with $\mathrm{Mg}, \mathrm{Cu}, \mathrm{Rh}, \mathrm{Cd}$, In, $\mathrm{Ba}, \mathrm{Ce}, \mathrm{Pb}$, and $\mathrm{U}\left(10 \mu \mathrm{g} \cdot \mathrm{L}^{-1}\right)$ from Perkin-Elmer was used for ICP-MS optimization procedures. ICP-MS calibration was established with a multielement standard solution with twenty-nine elements (ICP-MS Standard, Matrix: $5 \% \mathrm{HNO}_{3}$, Perkin Elmer Life and Analytical Sciences, $10 \mathrm{mg} \cdot \mathrm{mL}^{-1}$ ) and a Silicium ICP-Standard $\left(\mathrm{SiO}_{2}\right.$ in $\mathrm{NaOH} 2 \%$, Merck, $\left.1000 \mathrm{mg} \cdot \mathrm{L}^{-1} \mathrm{Si}\right)$.

2.1.3. Sample Preparation. As an analytical sample, beer is a very complex matrix with a relatively high content of different organic compounds originated from brewery processing and saturated with carbon dioxide. In order to eliminate errors caused by carbon dioxide bubbles, beer samples were firstly degasified by stirring $20 \mathrm{~mL}$ of each sample in normal conditions for 20 minutes. Beer samples were then filtered by passing a beer portion through a $0.45 \mu \mathrm{m}$ pore size membrane filter and for complete degasification process was repeated three times.

To avoid the clogging of the nebulizer, samples were prepared by simple 20 -fold dilution and acidification. In this survey, following a method described by Diegor et al. [8] for wines, $2.5 \mathrm{~mL}$ of ultrapure nitric acid was added to $2.5 \mathrm{~mL}$ of beer sample in a Teflon receptacle, tightly closed. Six such receptacles were inserted in a device made of six stainless steel cylinders mounted between two flanges to confer pressure resistance. The whole system was put in an oven at $200^{\circ} \mathrm{C}$ for 12 hours. A colorless solution resulted and ultrapure water was added up to $50 \mathrm{~mL}$. Thus the beer sample was diluted $1: 20$.

2.1.4. ICP-MS Determination. A primary analysis was performed using semiquantitative method available with PerkinElmer ICP-MS instrumentation. The analytical method was "Total Quant"; this is a software feature unique to the Elan ICP-MS systems for quantifying 81 elements with accuracy errors lower than $20 \%$ for most elements, in a sample by interpretation of the complete mass spectrum.

The operating conditions are listed below: nebulizer gas flow rates: $0.95 \mathrm{~L} \cdot \mathrm{min}^{-1}$; auxiliary gas flow: $1.2 \mathrm{~L} \cdot \mathrm{min}^{-1}$; plasma gas flow: $15 \mathrm{~L} \cdot \mathrm{min}^{-1}$; lens voltage: $7.25 \mathrm{~V}$; and ICP RF power: $1100 \mathrm{~W}$.

The experimental conditions used for the quantitative experiments were dwell time per amu: $50 \mathrm{~ms}$, sweeps/reading: 45, reading/replicates: 2, replicates: 2, time/run: $85 \mathrm{~s}$, and RPq: 0.25 . For each sample analysis three replicates were performed. Calibration curves were obtained with aqueous reference solutions for all analytes and the linearity of these (6 points) was considered acceptable $(R>0.999)$. The detection limits were calculated as the concentrations of an element that gave the standard deviation of a series of ten consecutive measurements of blank solutions. Detection limit values of elements as $\mu \mathrm{g} \cdot \mathrm{L}^{-1}$ in ICP-MS were found to be 0.003 for $\mathrm{Al}$, 0.0004 for As, 0.0009 for $\mathrm{Ba}, 0.0011$ for $\mathrm{Cd}, 0.0013$ for $\mathrm{Cu}$ and $\mathrm{Cr}, 0.012$ for $\mathrm{Ni}$ and $\mathrm{Zn}, 0.003$ for $\mathrm{Mn}$, and 0.004 for $\mathrm{Pb}$. The obtained standard deviation was in the range $2.2-10 \%$.

To ensure that the results obtained for the analyses were accurate, recovery tests were carried out for a beer sample spiked with a $2 \mu \mathrm{g} \cdot \mathrm{L}^{-1}$ standard solution. Recovery of each analyte was calculated in relation to added element concentration $\left(2 \mu \mathrm{g} \cdot \mathrm{L}^{-1}\right)$ for three replicates of this level of concentration $(n=3)$. The $\%$ of recovery for all elements was within the interval of $75-108 \%$.

2.2. Isotopic Ratio Mass Spectrometry (IRMS). The procedure of IRMS consists in measuring the isotope ratio of an analyte converted into a simple gas, isotopically representative of the original sample, before entering the ion source of an IRMS. The values were expressed in $\delta \%$ against international standards-Vienna Standard Mean Ocean Water for $\delta^{18} \mathrm{O}$ and $\delta^{2} \mathrm{H}$ and Vienna Pee Dee Belemnite for $\delta^{13} \mathrm{C}$. The isotopic values were expressed using the formula

$$
\delta=\left(\frac{R_{\text {sample }}}{R_{\text {standard }}}-1\right) \times 1000,
$$

where $R$ is the ratio between the heavy and the light isotopes and $R_{\text {sample }}$ is the isotopic ratio of the sample, while $R_{\text {standard }}$ is that of the reference material. 
TABLE 1: The concentration of major metals in studied beers (mean and RSD \%).

\begin{tabular}{|c|c|c|c|c|c|c|c|c|c|c|}
\hline \multirow{2}{*}{$\begin{array}{l}\text { Crt. } \\
\text { number }\end{array}$} & \multirow{2}{*}{ Sample code } & \multirow{2}{*}{ Producer } & \multirow{2}{*}{ Package type } & \multicolumn{7}{|c|}{ Metal concentration $\left[\mathrm{mg} \cdot \mathrm{L}^{-1}\right]$} \\
\hline & & & & $\mathrm{Na}$ & $\mathrm{Mg}$ & $\mathrm{Ca}$ & K & $\mathrm{P}$ & $\mathrm{Si}$ & $\mathrm{Fe}$ \\
\hline 1 & $\mathrm{~W}_{1}$ & Producer 1 & PET & $29.4 \pm 0.8$ & $38.2 \pm 1.7$ & $11.2 \pm 0.5$ & $88.6 \pm 3.5$ & $96.4 \pm 2.2$ & $13.4 \pm 0.5$ & $0.5 \pm 0.05$ \\
\hline 2 & $\mathrm{~W}_{2}$ & Producer 2 & Dose & $5.2 \pm 0.2$ & $41.2 \pm 1.7$ & $28.2 \pm 1.5$ & $86.2 \pm 3.6$ & $81.6 \pm 1.7$ & $11.4 \pm 0.5$ & $0.5 \pm 0.05$ \\
\hline 3 & $\mathrm{~W}_{3}$ & Producer 3 & Dose & $10.5 \pm 0.3$ & $69.5 \pm 2.2$ & $29.2 \pm 1.5$ & $135.2 \pm 12.8$ & $138.0 \pm 4.1$ & $15.6 \pm 0.7$ & $1.0 \pm 0.07$ \\
\hline 4 & $\mathrm{~W}_{4}$ & Producer 3 & Glass & $11.5 \pm 0.2$ & $73.2 \pm 3.5$ & $34.6 \pm 1.7$ & $138.2 \pm 13.3$ & $138.5 \pm 4.0$ & $12.8 \pm 0.5$ & $2.4 \pm 0.2$ \\
\hline 5 & $\mathrm{~W}_{5}$ & Producer 4 & Dose & $25.3 \pm 0.8$ & $50.1 \pm 3.0$ & $34.7 \pm 1.7$ & $114.4 \pm 10.2$ & $97.1 \pm 2.2$ & $11.3 \pm 0.5$ & $0.3 \pm 0.03$ \\
\hline 6 & $\mathrm{~W}_{6}$ & Producer 5 & Dose & $31.3 \pm 1.0$ & $47.8 \pm 3.4$ & $41.8 \pm 2.3$ & $107.5 \pm 10.5$ & $66.0 \pm 1.2$ & $14.2 \pm 0.6$ & $2.5 \pm 0.2$ \\
\hline 7 & $\mathrm{~W}_{7}$ & Producer 6 & Glass & $25.6 \pm 0.8$ & $84.7 \pm 5.8$ & $28.9 \pm 1.4$ & $154.8 \pm 14.0$ & $152.5 \pm 5.0$ & $13.5 \pm 0.5$ & $1.3 \pm 0.09$ \\
\hline 8 & $\mathrm{~W}_{8}$ & Producer 6 & Dose & $25.0 \pm 0.8$ & $84.3 \pm 5.0$ & $33.1 \pm 1.8$ & $147.3 \pm 10.9$ & $132.4 \pm 3.8$ & $14.4 \pm 0.6$ & $2.7 \pm 0.2$ \\
\hline 9 & $\mathrm{~W}_{9}$ & Producer 7 & Dose & $17.1 \pm 0.4$ & $42.1 \pm 1.7$ & $11.3 \pm 0.4$ & $104.1 \pm 8.5$ & $99.0 \pm 2.5$ & $13.1 \pm 0.5$ & $4.2 \pm 0.4$ \\
\hline 10 & $\mathrm{~W}_{10}$ & Producer 8 & Glass & $34.3 \pm 1.2$ & $71.6 \pm 3.3$ & $30.3 \pm 1.5$ & $144.4 \pm 10.3$ & $148.9 \pm 5.0$ & $13.3 \pm 0.5$ & $3.5 \pm 0.3$ \\
\hline 11 & $\mathrm{~W}_{11}$ & Producer 8 & Dose & $11.6 \pm 0.4$ & $78.7 \pm 4.2$ & $32.8 \pm 1.5$ & $138.6 \pm 13.0$ & $109.6 \pm 2.7$ & $15.0 \pm 0.7$ & $0.4 \pm 0.02$ \\
\hline 12 & $\mathrm{~W}_{12}$ & Producer 9 & Glass & $44.2 \pm 1.2$ & $84.2 \pm 5.5$ & $29.2 \pm 1.5$ & $197.0 \pm 18.5$ & $121.9 \pm 3.0$ & $12.9 \pm 0.5$ & $0.2 \pm 0.02$ \\
\hline 13 & $\mathrm{~W}_{13}$ & Producer 10 & Glass & $37.2 \pm 1.0$ & $62.4 \pm 2.0$ & $53.2 \pm 2.8$ & $115.3 \pm 9.5$ & $105.3 \pm 2.8$ & $13.7 \pm 0.5$ & $2.6 \pm 0.2$ \\
\hline 14 & $\mathrm{~W}_{14}$ & Producer 11 & Glass & $18.9 \pm 0.4$ & $58.5 \pm 2.8$ & $28.8 \pm 1.4$ & $129.2 \pm 10.4$ & $132.5 \pm 3.6$ & $15.2 \pm 0.7$ & $0.2 \pm 0.01$ \\
\hline 14 & $\mathrm{~W}_{15}$ & Producer 2 & PET & $8.8 \pm 0.2$ & $66.2 \pm 2.0$ & $62.2 \pm 3.4$ & $126.7 \pm 9.7$ & $130.7 \pm 3.6$ & $14.8 \pm 0.6$ & $0.6 \pm 0.03$ \\
\hline 16 & $\mathrm{~W}_{16}$ & Producer 12 & Dose & $13.8 \pm 0.3$ & $75.5 \pm 3.2$ & $37.2 \pm 1.7$ & $145.8 \pm 10.3$ & $107.9 \pm 2.5$ & $13.9 \pm 0.6$ & $2.3 \pm 0.2$ \\
\hline 17 & $\mathrm{~W}_{17}$ & Producer 12 & PET & $13.4 \pm 0.3$ & $75.2 \pm 4.0$ & $38.7 \pm 1.7$ & $154.3 \pm 13.9$ & $112.1 \pm 2.9$ & $15.7 \pm 0.8$ & $1.1 \pm 0.08$ \\
\hline 18 & $\mathrm{~W}_{18}$ & Producer 12 & Glass & $13.4 \pm 0.5$ & $71.3 \pm 3.7$ & $29.7 \pm 1.5$ & $144.4 \pm 10.0$ & $154.3 \pm 5.1$ & $13.9 \pm 0.6$ & $0.2 \pm 0.01$ \\
\hline 19 & $\mathrm{~W}_{19}$ & Producer 13 & PET & $154.9 \pm 10.2$ & $22.5 \pm 1.1$ & $15.9 \pm 0.8$ & $29.8 \pm 2.3$ & $89.0 \pm 1.9$ & $13.2 \pm 0.4$ & $2.3 \pm 0.2$ \\
\hline 20 & $\mathrm{~W}_{20}$ & Producer 14 & PET & $100.3 \pm 8.7$ & $29.7 \pm 1.1$ & $7.8 \pm 0.4$ & $39.8 \pm 4.0$ & $109.6 \pm 6.5$ & $20.0 \pm 1.5$ & $1.0 \pm 0.1$ \\
\hline
\end{tabular}

For oxygen-18 determination $5 \mathrm{~mL}$ of beer (neither centrifuged nor filtered) was equilibrated with $\mathrm{CO}_{2}$ for 15 hours according to the CEN:ENV 13141:1997 method at $25 \pm 0.1^{\circ} \mathrm{C}$. The carbon dioxide was then extracted and purified. The ${ }^{18} \mathrm{O}$ isotopic content of the water samples was then analyzed using a stable isotope ratio mass spectrometer IRMS (Delta $\mathrm{V}$ Advantage, Thermo Scientific). The isotopic values were calibrated against laboratory-used standards (working standard 1, with $\delta^{18} \mathrm{O}=-11.54 \pm 0.1 \%$; working standard 2, with $\delta^{18} \mathrm{O}=-7.14 \pm 0.1 \%$; and working standard 3 , with $\delta^{18} \mathrm{O}=$ $-2.96 \pm 0.1 \%$ )

The measurements of $\delta^{13} \mathrm{C}$ from dried beer were carried out on an elemental analyser (Flash EA1112 HT, Thermo Scientific), coupled with an isotope ratio mass-spectrometer IRMS (Delta V Advantage, Thermo Scientific). For the quality control of our analysis, three working standards were analyzed at the beginning of each sequence; then three replicas from each sample were measured. NBS-22 oil with a certified value of $-30.03 \%$ versus PDB (Pee Dee Belemnite) was used as standard. The limit of uncertainty was $\pm 0.2 \%$ for determination of both $\delta^{13} \mathrm{C}$ and $\delta^{18} \mathrm{O}$.

The one-way ANOVA analysis was applied on data obtained from ICP-MS measurements, meaning $\mathrm{Na}, \mathrm{Mg}, \mathrm{Ca}$, $\mathrm{K}, \mathrm{P}$, and $\mathrm{Al}$ concentrations. This analysis was performed in order to reveal if the means of the selected groups (PET, dose, and glass) were statistically different. Thus, as independent variable, type of packed material was chosen and mineral content was selected as dependent variable. Cluster analysis was performed for grouping the variables instead of cases. In our work, the cases were represented by each beer sample, from different producers, in different packed materials.

\section{Results and Discussion}

3.1. Inductively Coupled Plasma Mass Spectrometry (ICP-MS) Analysis. The determination of the total metal composition of beer, including major, minor, and trace metals, is of particular interest to brewers and consumers. Depending on the concentration and type, metals may be essential or toxic to the human body and can also affect the brewing process and beer quality in view of flavor stability and haze formation.

3.1.1. Major Elements. Table 1 presents the concentration of major metals in studied beers. The results given in Table 1 are the average concentration of three replicates analyses. The relative standard deviation (RSD\%) is given below the mean values.

The concentrations of $\mathrm{K}, \mathrm{Na}, \mathrm{Ca}$, and $\mathrm{Mg}$ were in the range of $29.87-197.08 \mathrm{mg} \cdot \mathrm{L}^{-1}, \quad 5.25-154.93 \mathrm{mg} \cdot \mathrm{L}^{-1}, \quad 7.80$ $62.23 \mathrm{mg} \cdot \mathrm{L}^{-1}$, and $22.59-84.76 \mathrm{mg} \cdot \mathrm{L}^{-1}$, respectively. Our results showed that the measured concentrations were in the range of concentrations reported by the literature $[3,5,9]$. For example, for beers produced in different countries, the following concentrations of macroelements were obtained: for Ca (40-140 mg. $\mathrm{L}^{-1}$-Britain, 29.0-86.2 $\mathrm{mg} \cdot \mathrm{L}^{-1}$-Spain, and 3.80-108 mg. $\mathrm{L}^{-1}$-Germany), for K (135-1100 mg. $\mathrm{L}^{-1}$-Britain, $22.9-496 \mathrm{mg} \cdot \mathrm{L}^{-1}$-Spain, and $22.9-496 \mathrm{mg} \cdot \mathrm{L}^{-1}$-Germany), for $\mathrm{Mg}\left(60-200 \mathrm{mg} \cdot \mathrm{L}^{-1}\right.$-Britain, $42.0-110 \mathrm{mg} \cdot \mathrm{L}^{-1}$-Spain, and 
23.7-266 mg. $\mathrm{L}^{-1}$-Germany), and for $\mathrm{Na}\left(21.90-230 \mathrm{mg} \cdot \mathrm{L}^{-1}\right.$ Britain, $\quad 3.95-103 \mathrm{mg} \cdot \mathrm{L}^{-1}$-Spain, and $1.19-120 \mathrm{mg} \cdot \mathrm{L}^{-1}$ Germany).

Regarding the characterization of beers according to the producers, it can be concluded that there are not notable differences between them. The beers manufactured by producers $13,14\left(\mathrm{~W}_{19}, \mathrm{~W}_{20}\right)$ present higher concentrations of sodium (for $\mathrm{W}_{19}$ over the maximum $\mathrm{Na}$ concentration limit in beer); meanwhile the quantities of $\mathrm{Mg}, \mathrm{K}$, and $\mathrm{P}$ are in the lower limits as compared with the other samples. The beers from producers $10\left(\mathrm{~W}_{13}\right), 2\left(\mathrm{~W}_{2}, \mathrm{~W}_{15}\right), 5\left(\mathrm{~W}_{6}\right)$, and 12 $\left(\mathrm{W}_{16}, \mathrm{~W}_{17}, \mathrm{~W}_{18}\right)$ occupy the first place in terms of average $\mathrm{Ca}$ content (concentration of $\mathrm{Ca}>35 \mathrm{mg} \cdot \mathrm{L}^{-1}$ ), while the beers manufactured by producers $6\left(\mathrm{~W}_{7}, \mathrm{~W}_{8}\right), 9\left(\mathrm{~W}_{12}\right)$, and 12 $\left(\mathrm{W}_{16}, \mathrm{~W}_{17}, \mathrm{~W}_{18}\right)$ occupy the first place in terms of average $\mathrm{Mg}$ content (concentration of $\mathrm{Mg}>74 \mathrm{mg} \cdot \mathrm{L}^{-1}$ ) and $\mathrm{K}$ content (concentration of $\mathrm{K}>141 \mathrm{mg} \cdot \mathrm{L}^{-1}$ ).

Among the same beer type manufactured by a certain producer, but different packed (glass, dose, or PET), no differences in macro elements content were observed suggesting that the same raw materials were used in the brewing process. So, for the beers manufactured by producer $3\left(\mathrm{~W}_{3}\right.$, $\left.\mathrm{W}_{4}\right)$, by producer $6\left(\mathrm{~W}_{7}, \mathrm{~W}_{8}\right)$, by producer $8\left(\mathrm{~W}_{10}, \mathrm{~W}_{11}\right)$, and by producer $12\left(\mathrm{~W}_{16}, \mathrm{~W}_{17}, \mathrm{~W}_{18}\right)$, there are not notable differences from mineral content point of view. For the beer manufactured by producer $2\left(\mathrm{~W}_{2}, \mathrm{~W}_{15}\right)$, there are some differences in terms of $\mathrm{K}, \mathrm{Ca}$, and $\mathrm{P}$, but insignificant. The essential elements for all beer samples follow a descending order as $\mathrm{K}>\mathrm{P}>\mathrm{Mg}>\mathrm{Na}>\mathrm{Ca}$.

3.1.2. Minor and Trace Elements. Metals found in investigated beers may originate also from many other adjunctive substances added during the brewing processes in order to control the fermentation and the maturation processes that might take place in beer. Another exogenous source of metals in beer can be the contamination from different components of the brewery equipment, for example, pipes, fluid lines, vessels, and tanks in which beer is fermented, conditioned, filtrated, carbonated, and packed, as well as the containers, for example, kegs, casks, and cans, in which the product of the final quality achieved is kept during storage and transport. Metal concentrations found in the investigated beers are given in Table 2. The results given in Table 2 are the average concentration of three replicates analyses.

Lead and cadmium are among the most abundant heavy metals and are particularly toxic $[10,11]$. The source of lead in beer and in other alcoholic beverages could be the contamination of raw material and/or technological processes. Arsenic is present in food and beverages because of its wide distribution in the environment from the sources being either natural or anthropogenic. Uncontrolled intake of As into the organism could be potentially toxic, and although the European Union Council [12] and the World Health Organization [13] established the permissible level $10 \mu \mathrm{g} \cdot \mathrm{L}^{-1}$ only for As in drinking water, the legislation concerning As contents in different kinds of foods and beverages including beer as a widely consumed beverage exists in some countries. Spain fixed at $100 \mu \mathrm{g} \cdot \mathrm{L}^{-1}$ as the tolerable amount of As in beer. Ireland [14] and the United Kingdom recommended $500 \mu \mathrm{g} \cdot \mathrm{L}^{-1}$ and Bulgaria, Czech Republic, Hungary, and Slovenia [15] recommended $200 \mu \mathrm{g} \cdot \mathrm{L}^{-1}$. The arsenic average content of studied beers was $3.55 \pm 0.19 \mu \mathrm{g} \cdot \mathrm{L}^{-1}$ ( $\mathrm{min}$ $0.6 \mu \mathrm{g} \cdot \mathrm{L}^{-1}$, max $8.72 \mu \mathrm{g} \cdot \mathrm{L}^{-1}$ ) while the cadmium average was $0.06 \pm 0.01 \mu \mathrm{g} \cdot \mathrm{L}^{-1}\left(\min <0.001, \max 0.42 \mu \mathrm{g} \cdot \mathrm{L}^{-1}\right)$. In our study, as well as in previously reported results, the lead and cadmium were present in low concentrations (Table 3). Some authors reported $\mathrm{Pb}$ content varying from 13 to $52 \mu \mathrm{g} \cdot \mathrm{L}^{-1}$ in Brazilian beer samples [1] or from 0.001 to $0.006 \mu \mathrm{g} \cdot \mathrm{L}^{-1}$ in Spanish beer samples and from 0.003 to $0.024 \mu \mathrm{g} \cdot \mathrm{L}^{-1}$ in German beer samples [5, 9]. Donadini et al. in a 2008 survey [16] reported that the average content of $\mathrm{Pb}$ in beers from the Italian market was $1.83 \mu \mathrm{g} \cdot \mathrm{L}^{-1}$; Iwegbue [17] reported $\mathrm{Pb}$ levels varying from $<0.001$ to $0.047 \mu \mathrm{g} \cdot \mathrm{mL}^{-1}$ in canned beers in Nigeria. A more complete survey was administered by Sherlock et al. [18] who monitored lead in beers from the UK market in 1986 showing a minimum of $10 \mu \mathrm{g} \cdot \mathrm{L}^{-1}$ and a maximum of $200 \mu \mathrm{g} \cdot \mathrm{L}^{-1}$.

Some upper limits for the metal concentrations in natural alcoholic drinking are given by Romania under number 975/1998 regarding the approval of hygienic and healthy food [19]. The upper limits for $\mathrm{As}, \mathrm{Cd}, \mathrm{Pb}, \mathrm{Zn}$, and $\mathrm{Cu}$ are 0.1 , $0.05,0.3,1.0$, and $1.0 \mathrm{mg} \cdot \mathrm{L}^{-1}$, respectively. The levels of the toxic metals, $\mathrm{As}, \mathrm{Cd}$, and $\mathrm{Pb}$, were very low, being much smaller than or just about $15 \mu \mathrm{g} \cdot \mathrm{L}^{-1}$ in all samples, much below the maximum allowable concentrations of these metals concentration.

Investigations to date concerning $\mathrm{Mn}$ have been focused on its importance as a yeast nutrient [20]. The content of this metal in beer is mainly influenced by the cereal raw materials and, during the brewing process, no significant changes have been reported $[21,22]$. The results for manganese were between 0.004 and $0.231 \mathrm{mg} \cdot \mathrm{L}^{-1}$.

Chromium $(\mathrm{Cr})$ is a trace element, which has generated increased interest in recent years due to its essential character [23]. The results for chromium were between 0.020 and $0.441 \mathrm{mg} \cdot \mathrm{L}^{-1}$. Nickel (Ni) is an essential element; it plays some important role in biological systems [24]. The results for $\mathrm{Ni}$ were between $<1 \times 10^{-6}$ and $0.187 \mathrm{mg} \cdot \mathrm{L}^{-1}$.

Copper comes from the raw materials and metal ions can also be introduced from substances added during brewing, such as hops, acids, bases, silica gel, other additives or stabilizers, and dilution water $[25,26]$. It is recommended that brewers not exceed copper concentrations greater than $0.05 \mathrm{mg} \cdot \mathrm{L}^{-1}$ [27]. For these reasons, copper determinations are deemed important and should be included in every beer analysis. Concentrations of iron and cooper were between 0.212 and $4.216 \mathrm{mg} \cdot \mathrm{L}^{-1}$ and between 0.026 and $0.073 \mathrm{mg} \cdot \mathrm{L}^{-1}$, respectively. Some authors reported $\mathrm{Fe}$ and $\mathrm{Cu}$ content varying between 0.096 and $0.920 \mu \mathrm{g} \cdot \mathrm{L}^{-1}$ and between 0.024 and $0.080 \mu \mathrm{g} \cdot \mathrm{L}^{-1}$, respectively, in Spanish beer samples, between 0.040 and $1.550 \mu \mathrm{g} \cdot \mathrm{L}^{-1}$ and between 0.019 and $0.800 \mu \mathrm{g} \cdot \mathrm{L}^{-1}$, respectively, in German beer samples, and between 0.041 and $1.060 \mu \mathrm{g} \cdot \mathrm{L}^{-1}$ and between 0.022 and $0.160 \mu \mathrm{g} \cdot \mathrm{L}^{-1}$, respectively, in other beer samples $[5,9,28,29]$. The highest mean levels of cooper were observed for the beers manufactured 


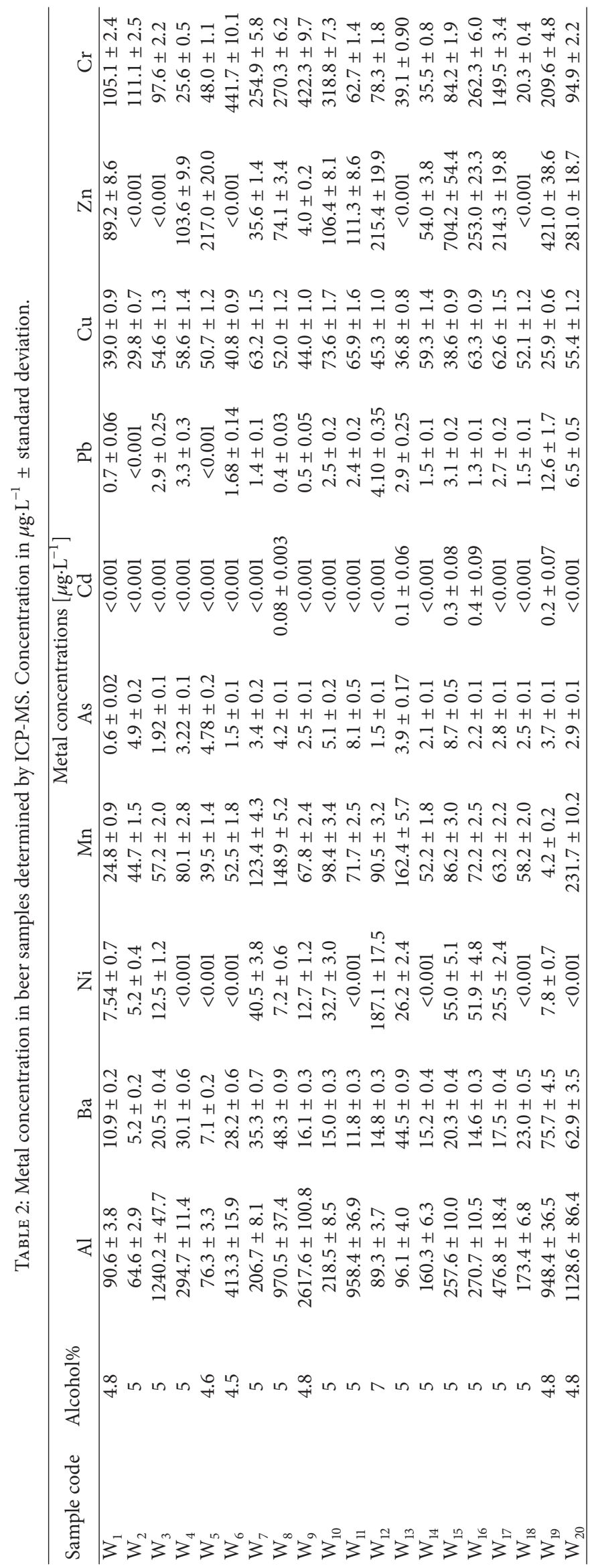


TABLE 3: The isotopic values $\left(\delta^{13} \mathrm{C}\right.$ and $\left.\delta^{18} \mathrm{O}\right)$ of investigated beers.

\begin{tabular}{|c|c|c|c|c|c|}
\hline Crt. number & Sample code & Producer & Package type & $\begin{array}{c}\delta^{18} \mathrm{O}_{\text {vsSMOW }}(\% \mathrm{o}) \pm \\
0.5(k=2)\end{array}$ & $\begin{array}{c}\delta^{13} \mathrm{C}_{\mathrm{vsPDB}}(\% \mathrm{o}) \pm 0.5 \\
(k=2)\end{array}$ \\
\hline 1 & $\mathrm{~W}_{1}$ & Producer 1 & PET & -11.6 & -23.9 \\
\hline 2 & $\mathrm{~W}_{2}$ & Producer 2 & Dose & -11.6 & -23.0 \\
\hline 3 & $\mathrm{~W}_{3}$ & Producer 3 & Dose & -10.2 & -27.0 \\
\hline 4 & $\mathrm{~W}_{4}$ & Producer 3 & Glass & -9.6 & -27.0 \\
\hline 5 & $\mathrm{~W}_{5}$ & Producer 4 & Dose & -10.0 & -23.1 \\
\hline 6 & $\mathrm{~W}_{6}$ & Producer 5 & Dose & -9.6 & -22.6 \\
\hline 7 & $\mathrm{~W}_{7}$ & Producer 6 & Glass & -9.8 & -26.3 \\
\hline 8 & $\mathrm{~W}_{8}$ & Producer 6 & Dose & -9.5 & -25.7 \\
\hline 9 & $\mathrm{~W}_{9}$ & Producer 7 & Dose & -10.7 & -23.1 \\
\hline 10 & $\mathrm{~W}_{10}$ & Producer 8 & Glass & -10.0 & -25.8 \\
\hline 11 & $\mathrm{~W}_{11}$ & Producer 8 & Dose & -11.5 & -26.2 \\
\hline 12 & $\mathrm{~W}_{12}$ & Producer 9 & Glass & -10.4 & -25.6 \\
\hline 13 & $\mathrm{~W}_{13}$ & Producer 10 & Glass & -10.1 & -23.1 \\
\hline 14 & $\mathrm{~W}_{14}$ & Producer 11 & Glass & -9.6 & -23.7 \\
\hline 15 & $\mathrm{~W}_{15}$ & Producer 2 & PET & -9.8 & -22.6 \\
\hline 16 & $\mathrm{~W}_{16}$ & Producer 12 & Dose & -10.5 & -26.2 \\
\hline 17 & $\mathrm{~W}_{17}$ & Producer 12 & PET & -10.9 & -26.5 \\
\hline 18 & $\mathrm{~W}_{18}$ & Producer 12 & Glass & -9.0 & -26.3 \\
\hline 19 & $\mathrm{~W}_{19}$ & Producer 13 & PET & -9.0 & -16.2 \\
\hline 20 & $\mathrm{~W}_{20}$ & Producer 14 & PET & -8.8 & -22.7 \\
\hline
\end{tabular}

by producer $8\left(\mathrm{~W}_{10}, \mathrm{~W}_{11}\right)$, with an average concentration of $0.069 \mathrm{mg} \cdot \mathrm{L}^{-1}$, while for the beer manufactured by producer $13\left(\mathrm{~W}_{19}\right)$ the smaller level of cooper was observed, an average value of $0.026 \mathrm{mg} \cdot \mathrm{L}^{-1}$.

Zinc constitutes about $33 \mathrm{mg} \cdot \mathrm{kg}^{-1}$ of an adult body mass and it is essential as a constituent of many enzymes involved in several physiological functions, such as protein synthesis and energy metabolism [30]. The results for zinc were between $<1 \times 10^{-6}$ and $0.704 \mathrm{mg} \cdot \mathrm{L}^{-1}$. Our data for the studied beers are below the maximum allowable concentrations of $\mathrm{Zn}$ and $\mathrm{Cu}$ from Romanian legislation [19].

It is interesting that, among the same beer type manufactured by a certain producer, there are high differences for $\mathrm{Zn}$ concentrations, for example, the beers manufactured by producer $2\left(\mathrm{~W}_{2}, \mathrm{~W}_{15}\right)$, whose $\mathrm{Zn}$ concentrations are $<1$ $\times 10^{-6} \mathrm{mg} \cdot \mathrm{L}^{-1}$ for beer $\mathrm{W}_{2}$ and $0.704 \mathrm{mg} \cdot \mathrm{L}^{-1}$ for beer $\mathrm{W}_{15}$, or the beers manufactured by producer $3\left(\mathrm{~W}_{3}, \mathrm{~W}_{4}\right)$, whose $\mathrm{Zn}$ concentrations are $<1 \times 10^{-6} \mathrm{mg} \cdot \mathrm{L}^{-1}$ for beer $\mathrm{W}_{3}$ and $0.103 \mathrm{mg} \cdot \mathrm{L}^{-1}$ for beer $\mathrm{W}_{4}$.

Our results are also compared with allowable limits for drinking water [13]. Typical regulated elements and allowable limits for $\mathrm{Ba}, \mathrm{Pb}, \mathrm{Cd}, \mathrm{Cu}, \mathrm{Zn}, \mathrm{Mn}, \mathrm{Al}, \mathrm{As}, \mathrm{Ni}$, and $\mathrm{Cr}$ are $0.7 \mathrm{mg} \cdot \mathrm{L}^{-1}, 0.01 \mathrm{mg} \cdot \mathrm{L}^{-1}, 0.003 \mathrm{mg} \cdot \mathrm{L}^{-1}, 2 \mathrm{mg} \cdot \mathrm{L}^{-1}$, $5 \mathrm{mg} \cdot \mathrm{L}^{-1}, 0.4 \mathrm{mg} \cdot \mathrm{L}^{-1}, 0.1 \mathrm{mg} \cdot \mathrm{L}^{-1}, 0.01 \mathrm{mg} \cdot \mathrm{L}^{-1}, 0.02 \mathrm{mg} \cdot \mathrm{L}^{-1}$, and $0.05 \mathrm{mg} \cdot \mathrm{L}^{-1}$, respectively. For $\mathrm{Al}, \mathrm{Ni}$, and $\mathrm{Pb}$, the concentration of ten samples and one sample, respectively, is above the limit for drinking water.
Beer is a widely consumed food product (very often packed in dose) and the measurement of the aluminium content in beer is of interest, and taking into account the above-mentioned concern regarding the possible association of an excessive aluminium intake with some disorders, it is of interest to measure the aluminium content in beer. It has been shown that levels range from 5 to $10 \mathrm{mg} \cdot \mathrm{L}^{-1}$ of dissolved aluminium in soft drinks or even higher in canned beers without affecting flavor, colour, or clarity. Aluminium in beer originates, mainly, from brewing raw materials (water, hops, malt, yeast, and adjuncts) [31,32]. The presence of aluminium was detected in analyzed beers, even though results varied widely $\left(0.064-2.617 \mathrm{mg} \cdot \mathrm{L}^{-1}\right)$.

In addition to the endogenous metal ion contact of foodstuffs, numerous steps during processing and packaging may add to the metal ion load. Another important factor to bear in mind is the packaging of beer [33]. Levels $>1.0 \mathrm{mg} \cdot \mathrm{L}^{-1}$ can be reached in foodstuffs due to possible transfer of aluminium from containers placed in an acid medium (optimum $\mathrm{pH}$ 3.8), although it was demonstrated that the use of varnished containers reduces this possibility [34]. It has been demonstrated by some researchers that the content of aluminium in canned beers is slightly higher than in bottled beers. In addition, the content of aluminium in doses beers increases during the period of storage [35]. The analytical results showed that the beers stored at room temperature contained more $\mathrm{Al}$ fact that it is one of the drinks with major content of this element and in addition its availability is high. 
Silicon is an important essential trace element; the recommended daily intake is about $10-25 \mathrm{mg} \cdot \mathrm{L}^{-1}$. The concentration of silicon in beer depends primarily on two factors. First, the silicon content of beer rises with the original wort concentration, and second, during decoction mashing, silicon is leached much more than in the case of infusion mashing [36]. The silicon concentrations in our study are varying between 11.30 and $20.02 \mathrm{mg} \cdot \mathrm{L}^{-1}$.

According to different researches, it has been suggested that silicon may interfere in the toxic-kinetic of aluminium. Silicon has a unique ability to bind the aluminum body and eliminate this harmful mineral in the body. Some studies on aluminium determinations point out that higher doses of silicon (up to $118 \mathrm{mg} \cdot \mathrm{L}^{-1}$ ) also administered in drinking water were shown to effectively prevent aluminium gastrointestinal absorption [37]. Since in our study the concentration of free aluminium ranges from 0.064 to $2.617 \mathrm{mg} \cdot \mathrm{L}^{-1}$ (and the concentration of silicon in beer ranges from 11.30 to $20.02 \mathrm{mg} \cdot \mathrm{L}^{-1}$ ) it would be sequestered by the silicon preventing any plausible absorption in the intestinal tract.

In the present study, comparisons were made between the aluminium concentrations of beers analyzed from doses and those from glass bottles to investigate whether the storage medium has influence on the chemical composition of beers. Results showed significantly higher aluminium in dose beers samples. For example, aluminium concentration of dose beers $\mathrm{W}_{3}\left(1.240 \mathrm{mg} \cdot \mathrm{L}^{-1}\right), \mathrm{W}_{8}\left(0.970 \mathrm{mg} \cdot \mathrm{L}^{-1}\right), \mathrm{W}_{11}$ $\left(0.958 \mathrm{mg} \cdot \mathrm{L}^{-1}\right)$, and $\mathrm{W}_{16}\left(0.270 \mathrm{mg} \cdot \mathrm{L}^{-1}\right)$ exceeds the aluminium concentration of bottled glass beer sample from the same producers $\mathrm{W}_{4}\left(0.294 \mathrm{mg} \cdot \mathrm{L}^{-1}\right), \mathrm{W}_{7}\left(0.206 \mathrm{mg} \cdot \mathrm{L}^{-1}\right), \mathrm{W}_{10}$ $\left(0.218 \mathrm{mg} \cdot \mathrm{L}^{-1}\right)$, and $W_{18}\left(0.173 \mathrm{mg} \cdot \mathrm{L}^{-1}\right)$, respectively.

3.2. Isotopic Ratio Mass Spectrometry (IRMS). Beers contain mainly four ingredients: water, malted barley, hops, and yeast. Beside these, beers might incorporate other minor ingredients like spices, natural flavors, or additional sugars or starch to increase the alcohol content of the final product. Malted barley extract contains primarily maltose [38] and maltotriose [39], and generally less fermentable forms of sugar, while some sugars as corn sugar are not only less expensive but also mostly sucrose, which is easily metabolized by the yeast. The addition of corn sugar to beer would lead to a decrease of brewing time and also would increase the alcohol content with a minimum content of ingredients [40].

The stable carbon isotope ratio has been widely used to trace the presence of sugar/alcohol obtained from $\mathrm{C}_{4}$ plants in beverages that are traditionally made from $\mathrm{C}_{3}$ plants because $\delta^{13} \mathrm{C}$ value of organic carbon reflects the photosynthetic pathway. This detection is based on the fact that the stable carbon isotope ratios (expressed as $\delta^{13} \mathrm{C}$ ) of $\mathrm{C}_{3}$ and $\mathrm{C}_{4}$ plants are different, with ranges from $-11 \%$ o to $-14 \%$ o for $\mathrm{C}_{4}$ plants and those of $\mathrm{C}_{3}$ plants varying between $-24 \%$ and $-32 \%$ [41-43]. In the $\mathrm{C}_{3}$ plants category included most of the grains, including barley, while the $\mathrm{C}_{4}$ plants category contain the plants which produce the most inexpensive sugars available on the market, being commonly used as additives to certain alcoholic beverages like maize, sorghum, and sugar cane [44, 45].
In beers, water is the main constituent, so in this case the principles of isotope hydrology could be applied [46]. The isotopic signature of hydrogen and oxygen $\left(\delta^{2} \mathrm{H}\right.$ and $\left.\delta^{18} \mathrm{O}\right)$ in water could vary due to isotope fractionation processes occurring during the water cycle. For the annual variation of isotopic ratios of hydrogen and oxygen $\left(\delta^{2} \mathrm{H}\right.$ and $\left.\delta^{18} \mathrm{O}\right)$ of water from a specific location, leading to a maximum in summer and a minimum in winter, the temperature effect is responsible for. The isotope ratio of precipitation varies temporally and spatially, resulting in typical regional precipitation isotope signature.

In Table 3 the isotopic values $\left(\delta^{13} \mathrm{C}\right.$ and $\left.\delta^{18} \mathrm{O}\right)$ of investigated beers are presented. The oxygen isotopic ratios $\delta^{18} \mathrm{O}$ are varying between -8.8 and $-11.6 \%$, reflecting the isotopic differences that appear both among the water sources available to each producer and different time periods in which the beer was manufactured. In our studied beer samples the $\delta^{13} \mathrm{C}$ values ranged between -16.2 and $-27 \%$; these results suggest the presence, in some samples, of different quantities of $\mathrm{C}_{4}$ plants in brewing process. In their work, Brooks et al. [40] found for European beer an average $\delta^{13} \mathrm{C}$ value of $-25.6 \pm$ $1.5 \%$, whereas all the German beers had a $\delta^{13} \mathrm{C}$ value more negative than $-25.5 \%$, indicating only $\mathrm{C}_{3}$ carbon in these samples. In their calculation of the ratio of $\mathrm{C}_{3}-\mathrm{C}_{4}$ carbon, they assume that a beer containing only $\mathrm{C}_{3}$ carbon source will have a $\delta^{13} \mathrm{C}$ lower than $-25.2 \%$. Mardegan et al. [47] assume taking into account the confidence interval equation proposed by Sleiman et al. [48] that beers with a mean of $\delta^{13} \mathrm{C}$ value of $-25.5 \%$ (in the range of -25.9 and $-26.5 \%$ ) contain $100 \%$ malt. In our study, the highest obtained $\delta^{13} \mathrm{C}$ value was for sample $\mathrm{W}_{19}\left(\delta^{13} \mathrm{C}=-16.2 \%\right.$ ), indicating mainly the use of $\mathrm{C}_{4}$ plants in its brewing process. Also, for samples $\mathrm{W}_{1}, \mathrm{~W}_{2}, \mathrm{~W}_{5}, \mathrm{~W}_{6}, \mathrm{~W}_{9}, \mathrm{~W}_{13}, \mathrm{~W}_{14}, \mathrm{~W}_{15}$, and $\mathrm{W}_{20}$ the use of $\mathrm{C}_{4}$ plants in brewing process was observed, but in a smaller quantity as compared with sample $\mathrm{W}_{19}$, suggesting a mixture of $\mathrm{C}_{3}$ and $\mathrm{C}_{4}$ sources. In contrast, the beer manufactured by producers $3,6,8,9$, and 12 had $\delta^{13} \mathrm{C}$ value more negative than $-25.6 \%$, indicating that only $\mathrm{C}_{3}$ plants were used in the brewing processes.

For beers manufactured by producers 3 and 6 which are bottled in dose or in glass, the isotopic differences which appear between the same beer types are in the range of experimental errors, suggesting that the beers were produced in the same period of time and the used row materials were the same. Also, for the beers manufactured by producers 8 and 12 , there are not notable differences in terms of $\delta^{13} \mathrm{C}$ values among the same beer type but bottled in different packages; meanwhile there are some notable differences in terms of $\delta^{18} \mathrm{O}$. This means that that during the brewing process the used row materials were the same, but most probably the beers were produced in different time periods and from here the notable differences in $\delta^{18} \mathrm{O}$ value.

From all these observations it can be concluded that, among the same beer type manufactured by a certain producer, but packed in glass, dose, or PET, there are no differences in terms of the raw materials that are used in the brewing process. 


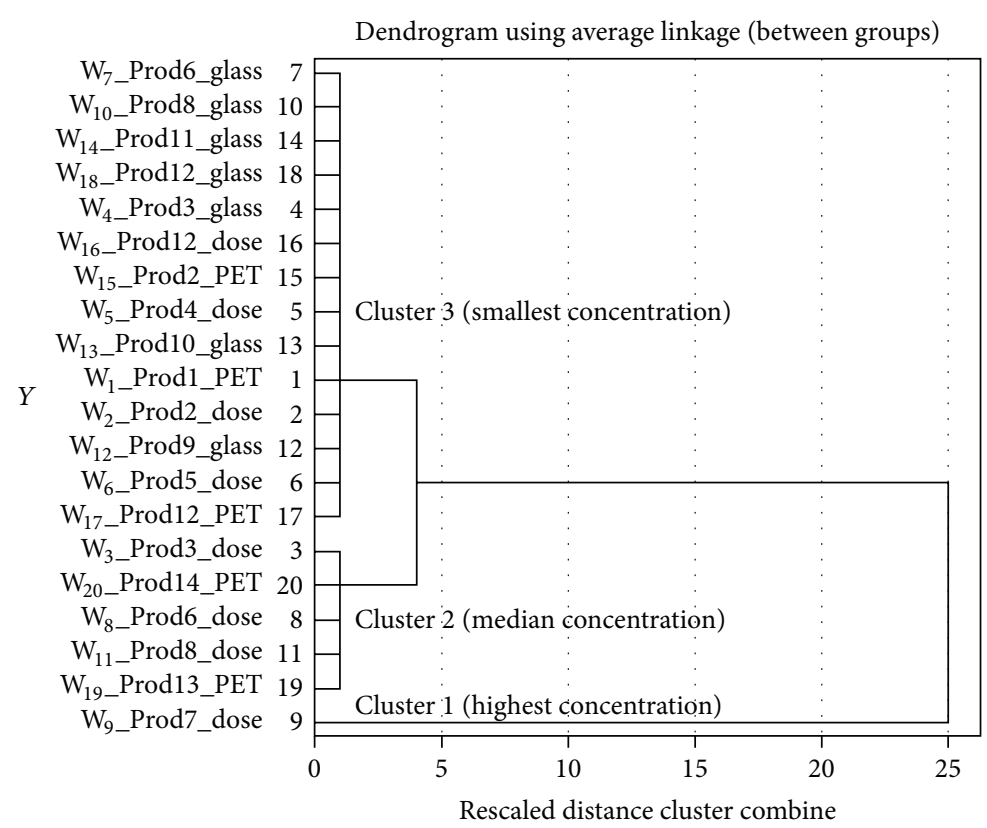

FIGURE 1: Dendrogram grouping the beer samples according to their mineral content.

3.3. Statistical Analysis. After running ANOVA analysis on data sets, it could be distinguished which element differed from one pack material to another. Three mineral elements, namely, $\operatorname{Mg}(p=0.057), \mathrm{K}(p=0.029)$, and $\mathrm{P}(p=0.016)$, had the $p$ value under 0.05 and could statistically differentiate between the three types of packed material. By conducting the post hoc test, namely, Tukey's test, the elements which differed from one packed materials to another were revealed. Thus, PET differed from glass through the $\mathrm{Mg}$ and $\mathrm{K}$ content ( $p$ value for $\mathrm{Mg}$ is 0.057 - even though it was a bit higher than 0.05 we took it into consideration-and for $\mathrm{K}$ was 0.029 , resp.). Glass from dose material differed only through the $\mathrm{P}$ content ( $p$ value was 0.016 ). Unexpectedly, Al could not make a statistically significant difference between dose, PET, and glass. One reason for this result could be that aluminium, when used as a component of beverages packaging (dose), is in most cases covered by a polymeric film (surface coating or laminated plastic film) and the level of migration is extremely low [49].

The most common classifying method is hierarchical cluster analysis. In this study the clustering method was the linkage between groups, with square Euclidian distance as an interval measure. All individual samples were grouped into three major clusters (Figure 1). The first cluster comprises 14 samples and the second one 5 samples and the last cluster is made of only one distinctive sample ( $\mathrm{W}_{9}$ _Prod7_dose).

In order to find out the differences between the three clusters, ANOVA was run again, this time having as independent variable the resulted cluster variable, obtained from previous analysis. From the six elements used in statistical interpretation, only $\mathrm{Al}$ has made a distinction between the three clusters. Thus, cluster 3, made from a single sample, had the highest $\mathrm{Al}$ content, cluster two had an average $\mathrm{Al}$ content of 1049.24, and the last one had an average of $\mathrm{Al}$ content of 206.384. In conclusion, when comparing groups of samples made according to the packaging, but when a general classification was tried, this was done according to the aluminum concentration in each sample.

\section{Conclusions}

The purpose of this study was the determination of heavy metal content in 20 different beers from Romanian markets, using inductively coupled plasma mass spectrometry (ICPMS). Overall, the study shows that the levels of the fourteen heavy metals studied are generally within safe limits and compare well with levels in similar foods from other parts of the world. The determination of beer by ICP-MS requires a system with good sensitivity as many of the elements are at trace concentrations. Unexpectedly, when ANOVA test compared means from groups realized according to the packaging materials (three groups, dose, PET, and glass), no statistically significant differences were observed in terms of Al. Three mineral elements, namely, $\mathrm{Mg}, \mathrm{K}$, and $\mathrm{P}$, had the $p$ value under 0.05 and could statistically differentiate between the three types of packed material. Cluster analysis successfully classified all beer samples into three clusters, having small, moderate, and high aluminium content.

From the stable isotope analysis it can be concluded that there are no ingredient differences among the same beer type stored in glass, dose, or PET, manufactured by the same producer. Thus, $\delta^{13} \mathrm{C}$ values of the beers produced by the same company are quite similar, while $\delta^{18} \mathrm{O}$ presents isotopic variations due to the different seasons in which the beers were made, variations that naturally appear during the hydrological cycle. Our study has shown that the analyzed beers indicated the presence of different plant types: $\mathrm{C}_{3}$, $\mathrm{C}_{3}-\mathrm{C}_{4}$ mixtures, and also $\mathrm{C}_{4}$, depending on producers. The 
highest content of ethanol produced from $\mathrm{C}_{4}$ plants was detected in $\mathrm{W}_{6}$ beer.

\section{Conflict of Interests}

The authors declare that there is no conflict of interests regarding the publication of this paper.

\section{Acknowledgment}

The financial support for this work was provided by the National Plan for Research-Development and Innovation 2007-2013 (44N/2009), PN09-44 0114.

\section{References}

[1] I. Matsushige and E. de Oliveira, "Determination of trace elements in Brazilian beers by ICP-AES," Food Chemistry, vol. 47, no. 2, pp. 205-207, 1993.

[2] V. R. Preedy, Beer in Health and Disease Prevention, Academic Press, New York, NY, USA, 2009.

[3] D. Bellido-Milla, J. M. Moreno-Perez, and M. P. HernándezArtiga, "Differentiation and classification of beers with flame atomic spectrometry and molecular absorption spectrometry and sample preparation assisted by microwaves," Spectrochimica Acta Part B: Atomic Spectroscopy, vol. 55, no. 7, pp. 855-864, 2000.

[4] B. Wyrzykowska, K. Szymczyk, H. Ichichashi, J. Falandysz, B. Skwarzec, and S.-I. Yamasaki, "Application of ICP sector field MS and principal component analysis for studying interdependences among 23 trace elements in Polish beers," Journal of Agricultural and Food Chemistry, vol. 49, no. 7, pp. 3425-3431, 2001.

[5] A. Alcázar, F. Pablos, M. J. Martín, and A. G. González, "Multivariate characterisation of beers according to their mineral content," Talanta, vol. 57, no. 1, pp. 45-52, 2002.

[6] D. Kruzlicova, Ž. Fiket, and G. Kniewald, "Classification of Croatian wine varieties using multivariate analysis of data obtained by high resolution ICP-MS analysis," Food Research International, vol. 54, no. 1, pp. 621-626, 2013.

[7] C. Karadaş and D. Kara, "Chemometric approach to evaluate trace metal concentrations in some spices and herbs," Food Chemistry, vol. 130, no. 1, pp. 196-202, 2012.

[8] W. Diegor, H. Longerich, T. Abrajano, and I. Horn, "Applicability of a high pressure digestion technique to the analysis of sediment and soil samples by inductively coupled plasma-mass spectrometry," Analytica Chimica Acta, vol. 431, no. 2, pp. 195207, 2001.

[9] D. E. Briggs, C. A. Boulton, P. A. Brookes, and R. Stevens, Brewing: Science and Practice, Woodhead Publishing, Cambridge, UK, 2004.

[10] J. M. Concon, Food Toxicology, Marcel Dekker, New York, NY, USA, 1998.

[11] N. M. M. Coelho, L. M. Coelho, E. S. de Lima, A. Pastor, and M. De La Guardia, "Determination of arsenic compounds in beverages by high-performance liquid chromatographyinductively coupled plasma mass spectrometry," Talanta, vol. 66, no. 4, pp. 818-822, 2005.

[12] "European Union Council Decision No. 2455/2001/EC establishing the list of priority substances in the field of water policy amending Directive 2000/60/EC," Official Journal of the European Union, p. 3311, 2001.

[13] World Health Organization, WHO Guidelines for DrinkingWater Quality, First Addendum to Third Edition, Recommendations, World Health Organization, Geneva, Switzerland, 2006.

[14] "Real Decreto 53 Reglamentación Tecnico-Sanitaria para la Elaboración, Circulación y Comercio de la Cerveza y la Malta Líquida," BOE 34, 1995.

[15] The British Food Manufacturing Industries Research Association, Food Legislation Surveys No. 6. Metallic Contaminants in Food-A Survey of International Prescribed Limits, The British Food Manufacturing Industries Research Association, Leatherhead, UK, 3rd edition, 1993.

[16] G. Donadini, S. Spalla, and G. M. Beone, "Arsenic, cadmium and lead in beers from the Italian market," Journal of the Institute of Brewing, vol. 114, no. 4, pp. 283-288, 2008.

[17] C. M. A. Iwegbue, "Composition and daily intakes of some trace metals from canned beers in Nigeria," Journal of the Institute of Brewing, vol. 116, no. 3, pp. 312-315, 2010.

[18] J. C. Sherlock, C. J. Pickford, and G. F. White, "Lead in alcoholic beverages," Food Additives and Contaminants, vol. 3, no. 4, pp. 347-354, 1986.

[19] Romanian Order Health Food, 975, 1998.

[20] C. Zufall and T. Tyrell, "The influence of heavy metal ions on beer flavour stability," Journal of the Institute of Brewing, vol. 114, no. 2, pp. 134-142, 2008.

[21] F. Mochaba, E. S. C. O'Connor-Cox, and B. C. Axcell, "Effects of yeast quality on the accumulation and release of metals causing beer instability," Journal of the American Society of Brewing Chemists, vol. 54, no. 3, pp. 164-171, 1996.

[22] S. Donhauser, "Über den Einfluß des Mangangehaltes der Würze auf die Gärung," Brauwelt, vol. 38, pp. 1616-1622, 1984.

[23] E. M. García, C. Cabrera, J. Sánchez, M. L. Lorenzo, and M. C. López, "Chromium levels in potable water, fruit juices and soft drinks: influence on dietary intake," Science of the Total Environment, vol. 241, no. 1-3, pp. 143-150, 1999.

[24] R. Pandey and S. P. Srivastava, "Spermatotoxic effects of nickel in mice," Bulletin of Environmental Contamination and Toxicology, vol. 64, no. 2, pp. 161-167, 2000.

[25] M. Moll, "Colloidal stability of beer," in Brewing Science, J. R. A. Pollock, Ed., p. 86, Academic Press, London, UK, 3rd edition, 1997.

[26] A. de Stefano and L. Montanari, "Minor components of beer: a review," Alcologia, vol. 8, no. 1, pp. 43-45, 1996.

[27] H. E. Weissler, "Quality control," in Handbook of Brewing, W. A. Hardwick, Ed., pp. 587-642, Marcel Dekker, New York, NY, USA, 1995.

[28] P. Pohl and B. Prusisz, "Pre-concentration of Cd, Co, Cu, Ni and $\mathrm{Zn}$ using different off-line ion exchange procedures followed by the inductively coupled plasma atomic emission spectrometric detection," Analytica Chimica Acta, vol. 502, no. 1, pp. 83-90, 2004.

[29] P. Viñas, N. Aguinaga, I. López-García, and M. HernándezCórdoba, "Determination of cadmium, aluminium, and copper in beer and products used in its manufacture by electrothermal atomic absorption spectrometry," Journal of AOAC International, vol. 85, no. 3, pp. 736-743, 2002.

[30] P. C. Onianwa, A. O. Adeyemo, O. E. Idowu, and E. E. Ogabiela, "Copper and zinc contents of Nigerian foods and estimates of the adult dietary intakes," Food Chemistry, vol. 72, no. 1, pp. 8995, 2001. 
[31] J. A. T. Pennington and J. W. Jones, Aluminium and Health: A Critical Review, Marcel Dekker, New York, NY, USA, 1989.

[32] R. C. Massey and D. Taylor, Aluminium in Food and the Environment, Royal Society of Chemistry, London, UK, 1991.

[33] C. A. Blanco, D. Sancho, and I. Caballero, "Aluminium content in beers and silicon sequestering effects," Food Research International, vol. 43, no. 10, pp. 2432-2436, 2010.

[34] M. Repetto, Toxicología Avanzada, Díaz de Santos, S.A., Madrid, Spain, 1995.

[35] M. Sĕruga, J. Grgić, Z. Grgić, and B. Sĕruga, "Aluminium content of beers," Zeitschrift für Lebensmitteluntersuchung und -Forschung A, vol. 204, no. 3, pp. 221-226, 1997.

[36] P. Dostalek, "Silicon in lager beers and its balance during the brewing process," in Proceedings of the World Brewing Congress, Portland, Ore, USA, July 2012.

[37] M. Bellés, D. J. Sánchez, M. Gómez, J. Corbella, and J. L. Domingo, "Silicon reduces aluminum accumulation in rats: relevance to the aluminum hypothesis of Alzheimer disease," Alzheimer Disease and Associated Disorders, vol. 12, no. 2, pp. 83-87, 1998.

[38] J. S. Hough, The Biotechnology of Malting and Brewing, Cambridge University Press, Cambridge, UK, 1985.

[39] A. W. Phillips, "Utilization by yeasts of the carbohydrates wort," Journal of the Institute of Brewing, vol. 61, no. 2, pp. 122-126, 1955.

[40] J. R. Brooks, N. Buchmann, S. Phillips et al., "Heavy and light beer: a carbon isotope approach to detect $\mathrm{C}_{4}$ carbon in beers of different origins, styles, and prices," Journal of Agricultural and Food Chemistry, vol. 50, no. 22, pp. 6413-6418, 2002.

[41] M. H. O'Leary, "Carbon isotope fractionation in plants," Phytochemistry, vol. 20, no. 4, pp. 553-567, 1981.

[42] M. H. O'Leary, "Carbon isotopes in photosynthesis," BioScience, vol. 38, no. 5, pp. 328-336, 1988.

[43] H. L. Schmidt and F. J. Winkler, "Einige Ursachen der Variationsbreite von $\delta^{13} \mathrm{C}$-Werten bei $\mathrm{C}_{3}$ - und $\mathrm{C}_{4}$-Pflanzen," Berichte der Deutschen Botanischen Gesellschaft, vol. 92, pp. 185-191, 1979.

[44] W. A. Simpkins and D. Rigby, "Detection of the illicit extension of potable spirituous liquors using ${ }^{13} \mathrm{C}:{ }^{12} \mathrm{C}$ ratios," Journal of the Science of Food and Agriculture, vol. 33, no. 9, pp. 898-903, 1982.

[45] L. Pissinatto, L. A. Martinelli, R. L. Victoria, and P. B. D. Camargo, "Stable carbon isotopic analysis and the botanical origin of ethanol in Brazilian brandies," Food Research International, vol. 32, no. 10, pp. 665-668, 1999.

[46] W. Papesch and M. Horacek, "Forensic applications of stable isotope analysis: case studies of the origins of water in mislabeled beer and contaminated diesel fuel," Science and Justice, vol. 49, no. 2, pp. 138-141, 2009.

[47] S. F. Mardegan, T. M. B. Andrade, E. R. de Sousa Neto et al., "Stable carbon isotopic composition of Brazilian beers-a comparison between large- and small-scale breweries," Journal of Food Composition and Analysis, vol. 29, no. 1, pp. 52-57, 2013.

[48] M. Sleiman, W. G. Venturini Filho, C. Ducatti, and T. Nojimoto, "Carbon and nitrogen stable isotopes used to determine the percentage of malt in Pilsen beer," Brazilian Journal of Food Technology, vol. 11, no. 2, pp. 95-102, 2008.

[49] P. K. T. Oldring and U. Nehring, Packaging Materials: 7. Metal Packaging for Foodstuffs, ILSI Europe Report Series, 2007. 

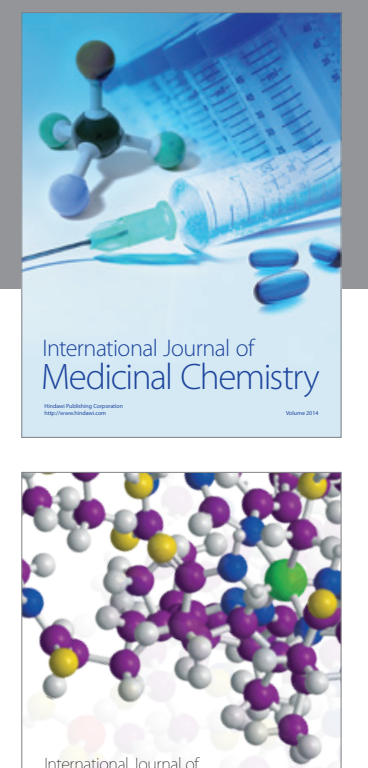

\section{Carbohydrate} Chemistry

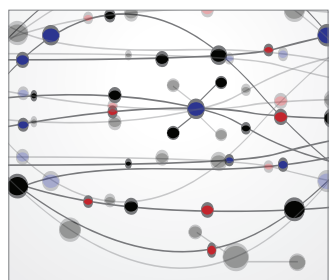

The Scientific World Journal
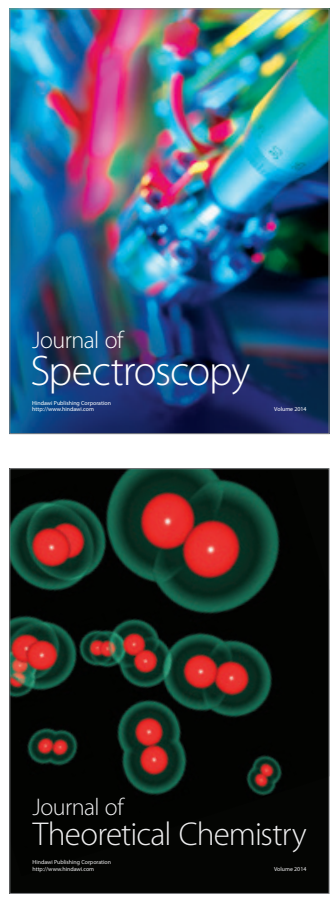
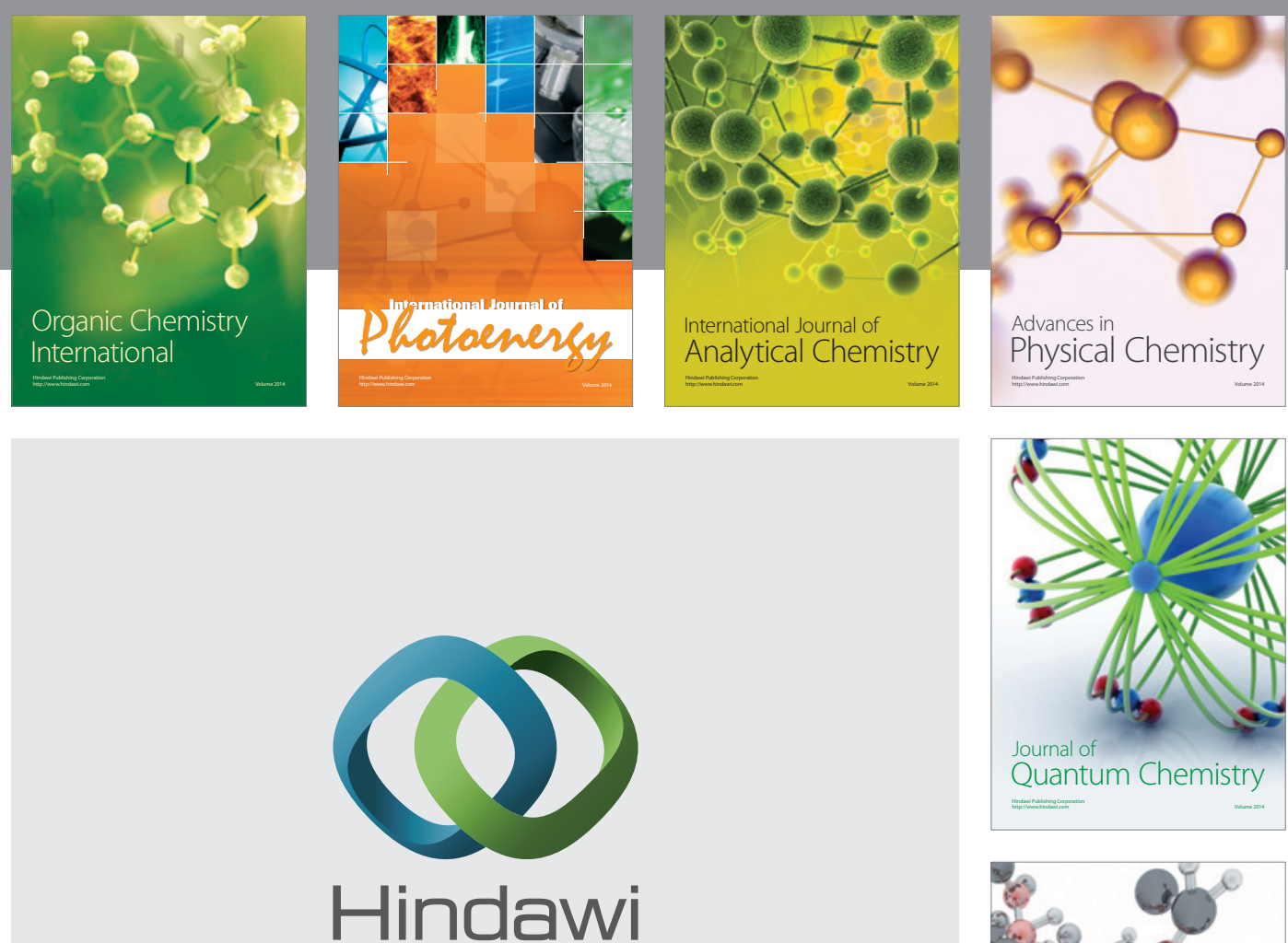

Submit your manuscripts at

http://www.hindawi.com

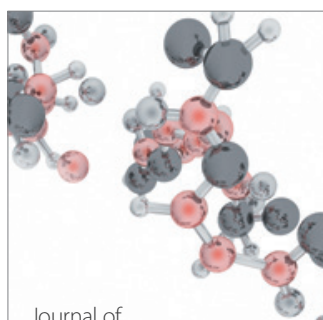

Analytical Methods

in Chemistry

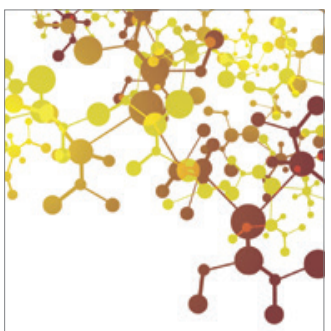

Journal of

Applied Chemistry

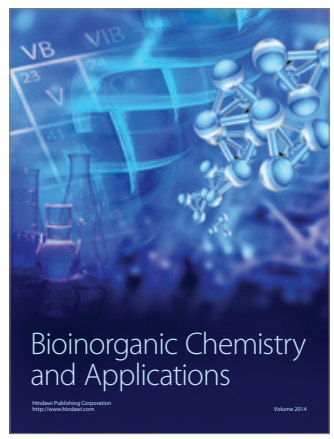

Inorganic Chemistry
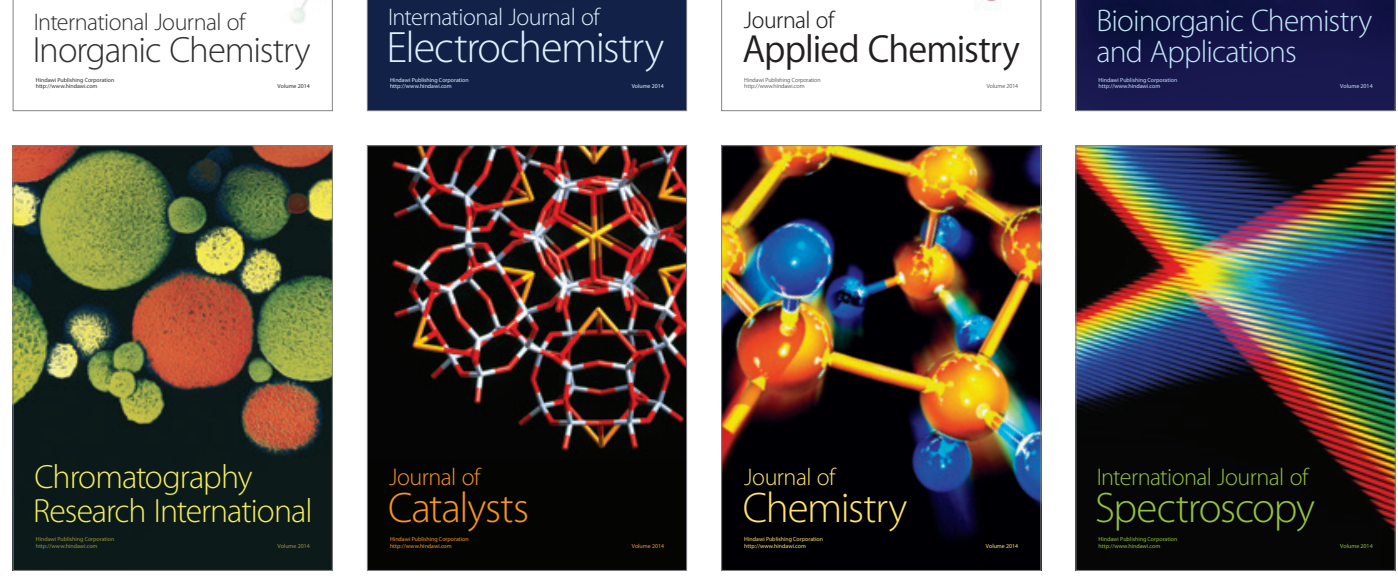